\title{
$\frac{100}{\mathrm{WiT}}$ RPESS
}

\author{
WITOLD WRZESIEŃ*
}

\section{POKOLENIOWOŚĆ W ŚWIECIE SMARTFONÓW, ALGORYTMIZACJI I SZTUCZNEJ INTELIGENCJI}

\section{WPROWADZENIE}

Żyjemy w czasach coraz szybciej zachodzących przemian cywilizacyjnych, za które w przeważajacej mierze odpowiedzialny jest dynamiczny rozwój nowoczesnych technologii informatycznych. Powstanie jednej wspólnej telefoniczno-internetowej przestrzeni, wraz z wprowadzeniem (mniej więcej w tym samym czasie, czyli w pierwszej dekadzie XXI w.) zbioru możliwości umownie określanych mianem Web 2.0, zwiększyło potencjał rozwoju wielu obszarów współtworzonej przez nas kultury konsumpcyjnego kapitalizmu. Dzięki powszechnej, coraz bardziej złożonej aktywności w sieci staliśmy się wszyscy dostarczycielami niezliczonej ilości informacji, a ich skomplikowane analizy (znacznie przekraczające możliwości obliczeniowe naszego mózgu) umożliwiły stworzenie podstaw toczącej się właśnie technologiczno-cywilizacyjnej rewolucji. Systemy analiz Big Data, zautomatyzowane systemy podejmowania decyzji (algorithmic decision-making, ADM), deep learning w uczeniu maszynowym, prowadzace do coraz doskonalszych form sztucznej inteligencji (AI), Internet rzeczy (IoT) to tylko wybrane przykłady jej symptomów, z czego konsekwencjami już zaczynamy się mierzyć. Coraz częściej o losach ludzi decydują nie inni ludzie, czy nawet ślepy traf, ale liczby, punkty, wyniki - rezultaty operacji przeprowadzanych przez algorytmy. Najintensywniej procesy te zaznaczają swoją obecność w społeczeństwach Zachodu (do których zaliczam też społeczeństwo polskie) oraz w społeczeństwach wysoko rozwiniętych państw Azji, takich jak Japonia, Korea Południowa czy Chiny. Niemniej jednak, ze względu na postępująca globalizację, różnorodne przejawy interesujących nas przemian odnajdziemy współcześnie niemal w każdym zakątku świata.

* Witold Wrzesień, Uniwersytet im. Adama Mickiewicza w Poznaniu, wrzesien@amu.edu.pl, https://orcid.org/0000-0002-4886-6351 
Tytułowa pokoleniowość to termin wprowadzony do socjologii przez Jana Garewicza ${ }^{1}$. W swoich rozważaniach posługuję się nim nieco inaczej niż wspomniany autor, przyjmując, że jest to stan naszej zbiorowej i indywidualnej pokoleniowej oryginalności/ „wyjątkowości”, zarówno rozpoznawany z zewnątrz, jak i niekiedy mniej lub bardziej uświadamiany przez nas samych - uczestników ciagłego procesu wymiany pokolen. To zbiór wielu, powiązanych ze soba elementów, stanowiących o szczególnym profilu poszczególnych grup pokoleniowych, które dzięki nim zyskuja łatwo rozpoznawalne miejsce w historii.

Do charakteryzowania pokoleniowości wykorzystuję pojęcia tożsamości społecznej pokolenia, poczucia pokoleniowej przynależności oraz cech identyfikacyjnych pokolenia. Pokoleniowość kształtuje się w czasie naszej największej pokoleniotwórczej aktywności, która przypada mniej więcej na wiek 19-26 lat. Wówczas to, w okresie naszej „dominacji” na rynku kultury młodzieżowej, oprócz własnej osobowości i indywidualnej tożsamości kształtujemy też społeczną tożsamość naszego pokolenia.

Tożsamość społeczną pokolenia rozumiem w sensie obiektywnym - to symboliczna przynależność do czasowych i terytorialnych segmentów rzeczywistości społecznej, nasze „tu i teraz młodości”, rozpoznawalne „z zewnątrz” przez naszych obserwatorów oraz wpływające na manifestowane przez nas (też w dalszym życiu) postawy, normy, wartości czy realizowane wzory zachowań. Natomiast gdy ową tożsamość społeczną własnego pokolenia sobie uświadamiamy, to doświadczamy poczucia pokoleniowej przynależności, na którą składają się takie elementy, jak: a) poczucie wspólnoty doświadczeń, które moga w mniejszym lub większym stopniu wyznaczać ścieżki życiowej kariery; b) poczucie wspólnoty interesów, norm, wartości i wzorów zachowań, manifestujace się $\mathrm{w}$ realizowanym stylu życia oraz c) poczucie solidarności.

Poczucie pokoleniowej przynależności, to pokoleniowość w sensie subiektywnym, wewnętrznym - świadomość uczestnictwa w kształtującym się pokoleniu. Tymczasem tożsamość społeczna pokolenia to fakt obiektywny, zbiór cech, które wyróżniają daną zbiorowość czy grupę w procesie wymiany pokoleń - zewnętrzna oznaka pokoleniowości, którą poznajemy poprzez manifestowane $\mathrm{w}$ stylu życia cechy identyfikacyjne własnych grup pokoleniowych. Te z kolei są zestawami czynników „umiejscawiajacych w czasie” kolejne grupy pokoleniowe, do których zaliczam: normy, wartości, wzory, wzorce, zestawy znaków i symboli, które w zależności od sytuacji społecznej mogą - wszystkie razem lub tylko niektóre z nich - wpływać na opinie, postawy i podejmowane działania. Cechy te tworzą dalej bardziej złożone struktury, odpowiedzialne za zróżnicowania takich sfer aktywności jednostek, jak: praca, czas wolny, uczestnictwo w kulturze, relacje pomiędzy bliskimi generacjami ${ }^{2} \mathrm{i}$ moda.

\footnotetext{
1 Garewicz (1983).

${ }^{2}$ Bliska generacja to obok pokoleniowej elity jedna $\mathrm{z}$ form grup pokoleniowych. Bliskie generacje swoim zasięgiem obejmują wszystkich przedstawicieli kilku roczników i są kolejnymi, następującymi po sobie ogniwami, odpowiedzialnymi za ciagłość procesu wymiany pokoleń. To zbiorowość o cechach poszerzonej grupy rówieśniczej o maksymalnym przedziale wieku zamykającym się w granicach 5-8 lat. Szerzej jej opisem zajmuję się gdzie indziej, zob. Wrzesień (2003), (2009).
} 
W ostatnich latach modyfikacje różnorodnych subświatów konstruowanych przez ludzi rzeczywistości ${ }^{3}$, od polityki i gospodarki zaczynając, a na życiu rodzinnym kończąc, nie ominęły również subświata pokoleń. Oprócz nowych form tworzenia pokoleniowej tożsamości nowo powstających grup pokoleniowych ${ }^{4}$, niezwykle interesująco zarysowują się również zmiany w pokoleniach juz istniejacych, a stale obecnych na pokoleniowej scenie. W przestrzeniach tych pojawiaja się dzisiaj nowe formy pokoleniowych dyferencjacji obserwowane wewnątrz oraz pomiędzy pokoleniami. Z tego też względu w niniejszym tekście podjęta zostanie próba wstępnej diagnozy zmian w świecie pokoleń, które uaktywniają się w konsekwencji dynamicznego rozwoju technologii informatycznych. Podstawą rozważań zawartych w prezentowanym artykule będzie teoria pokoleń ${ }^{5}$ oraz doświadczenia zgromadzone przez autora w pracy badawczej ${ }^{6}$. Celem artykułu jest rozważenie specyfiki wpływu rozwoju nowoczesnych technologii informatycznych na pokoleniowość współczesnych pokoleń oraz prognoza rozwoju omówionych tendencji w najbliższej przyszłości.

\section{CZAS ALGORYTMIZACJI I SZTUCZNEJ INTELIGENCJI A POKOLENIOWOŚĆ DZISIAJ}

W ostatnich latach algorytm stał się pojęciem niemal magicznym, a algorytmizacja, czyli stosowanie algorytmów jako swoistych uniwersalnych środków zaradczych, pomocnych w realizacji różnorodnych zadań, zagościła prawie we wszystkich obszarach ludzkiej aktywności.

Algorytm to „przepis postępowania prowadzacy do rozwiązania ustalonego problemu, określający ciąg czynności elementarnych, które należy w tym celu wykonać. [...] Może zawierać definicje obiektów (danych), na których te czynności są przeprowadzane”7. Jego wykonawca „może być człowiek lub urządzenie automatyczne (np. komputer) zdolne do wykonywania poleceń w odpowiedzi na sygnały reprezentujące te polecenia”. „Algorytm nie jest jakimśs konkretnym obliczeniem, lecz metoda, którą się stosuje podczas dokonywania jakiegoś obliczenia”. „Algorytmy różnią się, gdy idzie o wymaganą pamięć i moc obliczeniowa, przyjmowane z góry ukierunkowanie indukcyjne, łatwość włączenia treści z zewnątrz oraz przejrzystości mechanizmów ich działania dla analizującego je człowieka" ${ }^{10}$.

\footnotetext{
3 Berger, Luckmann (1991).

${ }^{4}$ Gardner, Davis (2013); Wrzesień (2015); Twenge (2017).

${ }^{5}$ Mannheim (1928/1952); Simmel (1908); Ortega y Gasset (1929); Ossowska (1963); Mikułowski-Pomorski (1968); Garewicz (1983); Świda-Ziemba (1999).

${ }^{6}$ Wrzesień (2003), (2009), (2015), (2016), (2017a).

7 Encyklopedia PWN.

8 Encyklopedia PWN.

${ }^{9}$ Harari (2018): 42.

10 Bostrom (2016): 28-29.
} 
Algorytmy towarzyszą nam od wieków, stanowiąc część kultury technologicznej człowieka. Współcześnie jednak zyskały całkiem nową moc. Począwszy od pracy magisterskiej Claude’a Shannona ${ }^{11}$, tworzącej podwaliny pod współczesne nauki komputerowe ${ }^{12}$, stopniowy rozwój technologii informatycznych, opierających się na wciąż udoskonalanych algorytmach, z jednej strony zaowocował powstaniem coraz doskonalszych form sztucznej inteligencji ${ }^{13}$, z drugiej natomiast - doprowadził do wykreowania swoistej ideologii, w której algorytm zajął centralne miejsce ${ }^{14}$. Stopniowo, bez rozgłosu, ideologia algorytmizacji zaczęła swym zasięgiem obejmować kolejne obszary otaczajacych nas i współtworzonych przez nas rzeczywistości.

Ten wyjątkowy status we współczesnej cywilizacji algorytm zawdzięcza kilku równoległym i zazębiającym się procesom, przebiegającym w paru obszarach. Innowacyjne sposoby, zarówno analizy informacji, jak i wynikających z nich możliwości wywierania wpływu, docenione zostały najpierw przez świat wielkich korporacji. Szczególne miejsce w tych przestrzeniach odgrywają algorytmy wykorzystywane w sektorze finansów, stosowane na przykład do przeprowadzania operacji giełdowych ${ }^{15}$. Jednakże cała ekonomia big data, czyli śledzenie ruchu w sieci, a poprzez to naszych potrzeb, działań i potencjalnej siły nabywczej, to dziśs chleb powszedni wszystkich podmiotów, które chcą się liczyć w biznesie.

Fundamentalną rolę odegrały tu firmy internetowe, takie jak np. Google, Facebook czy Amazon, które dzięki olbrzymim możliwościom obliczeniowym i stałemu gromadzeniu danych stały się nadzwyczaj cennymi partnerami w działaniach ekonomicznych, co w pierwszej kolejności znalazło swoje odzwierciedlenie w nowych formach marketingu i reklamy. Stosowane w przeglądarkach internetowych i serwisach społecznościowych algorytmy (np. Edge Rank Facebooka), określające wyświetlanie poszczególnych komunikatów, postów, stron, ich wybór oraz kolejność, wraz z dokonywanymi korektami treści i szat graficznych reklam kierowanych do odbiorców uprzednio wyselekcjonowanych na podstawie kolejnych algorytmów, okazały się nie tylko doskonałymi narzędziami marketingowymi, ale również skutecznymi mechanizmami społecznej kontroli, posiadającymi zdolność nie tylko ukierunkowywania zainteresowań, ale kształtowania preferencji, opinii, postaw, a w konsekwencji i potencjalnych działań (nie tylko w sieci).

W tym miejscu wkraczamy w kolejny obszar, w którym algorytm skutecznie utorował sobie drogę do zajęcia uprzywilejowanej pozycji w otaczajacej nas współczesności - świat polityki i sprawowania władzy. Zastosowanie potencjału obliczeniowego big data i opartych na nich mechanizmów wywierania wpływu na wyborców podczas kampanii Baracka Obamy w roku 2012 czy Donalda Trumpa w 2016 (z późniejszą aferą Cambridge Analytica) uzmysłowiło większości obywateli demokratycznego świata, że wraz z algorytmizacją subświata

\footnotetext{
11 Shannon (1940).

12 Kaplan (2019): 14.

13 Kaplan (2019); Bostrom (2016); Ito (2019).

${ }_{14}$ Krzysztofek (2012); Kreft (2018); Harari (2018).

15 Zob. O’Neil (2017); Bostrom (2016).
} 
kampanii wyborczych zakres oddziaływań manipulacyjnych w świecie polityki i sprawowania władzy wkroczył w nowy wymiar skuteczności. Zdecydowanie najbardziej kontrowersyjnym (dla zachodniej, demokratycznej świadomości obywatelskiej) zastosowaniem algorytmizacji w przestrzeniach władzy i społecznej kontroli jest chiński System Zaufania Społecznego (Social Credit System $)^{16}$. Jednakże również $\mathrm{w}$ świecie zachodnim dzięki coraz powszechniejsze$\mathrm{mu}$ wdrażaniu zautomatyzowanych systemów podejmowania decyzji (ADM) ${ }^{17}$ wiele działań dotychczas wykonywanych przez ludzi przejmuja komputery, wykorzystujące odpowiednio przygotowane w tym celu algorytmy. Sądownictwo i prewencja przestępstw, rynek pracy, finanse i bankowość, system edukacji, opieka zdrowotna (w tym walka z pandemią COVID-19), opieka społeczna, nauka, dostęp do informacji i uczestnictwa w kulturze - we wszystkich tych przestrzeniach algorytmy bądź to oceniają zróżnicowane cechy ludzi i/lub ich kompetencje, bądź tworzą modele predyktywne ${ }^{18}$, nie tylko pomagając w podejmowaniu decyzji przez człowieka, lecz także samodzielnie rozstrzygnięcia te podejmując. A decyzje te, zgodnie z ideologia algorytmizacji, prezentowane sa jako działania neutralne, obiektywne, w pełni godne zaufania ${ }^{19}$, a co za tym idzie - niepodważalne. Oczywiście, gdy ustalenia dotyczą wyboru seriali w Netflixie czy listy muzycznej Spotify konsekwencje nie są poważne, ale jeśli weźmiemy pod uwagę decyzje kredytowe, zdobycie posady, zakwalifikowanie się do szkoły czy wysokość wyroku, nie są to już tylko niewielkie modyfikacje preferencji czy stylu aktywności w czasie wolnym, to już rzeczywiste manipulowanie ścieżkami życiowych karier ${ }^{20}$. Za wszystkimi algorytmami kryją się ich twórcy i w tym tkwi ich największa słabość, z reguły bowiem algorytmy, „które z założenia mają być bezstronne, odzwierciedlają z góry założone cele oraz osobiste przekonania" ${ }^{21}$.

Sprawy jeszcze bardziej komplikują się w sytuacjach, gdy w zasygnalizowanych powyżej przestrzeniach algorytmy mają cechy sztucznej inteligencji (SI). Sztuczna inteligencja (artificial intelligence, AI), termin wprowadzony przez Johna McCarthy'ego w 1955 r., z jednej strony odniósł niespodziewany marketingowy sukces, z drugiej - przez swoją metaforyczną nieprecyzyjność - nie doczekał się jednoznacznego sposobu definiowania. W najbardziej ogólnym zarysie termin sztuczna inteligencja kojarzony jest z działaniami maszyn/ komputerów wykorzystujących specjalnie przygotowane oprogramowanie pozwalające im na samodzielne podejmowanie czynności zazwyczaj dotychczas wykonywanych przez ludzi. Jest też utożsamiany z dziedziną nauki zajmująca się tworzeniem systemów zarówno wspomagających, jak i wyręczających człowieka w tych czynnościach. Współcześnie sztuczna inteligencja dzielona jest na wąską (słaba) SI i ogólną (silna, rozszerzona) SI (artificial general intelligence, AGI). Wąska SI zawdzięcza swoją nazwę temu, że przeznaczona jest do

\footnotetext{
${ }^{16}$ Zob. China Law Translate (2020); Kopka (2018).

17 Valentine (2019); O’Neil (2017).

${ }^{18}$ Kaplan (2019): 45.

19 Beer (2017).

${ }^{20}$ Zob. O’Neil (2017); Iwasiński (2016).

${ }^{21}$ O’Neil (2017): 19.
} 
wykonywania wąsko sprecyzowanych zadań (np. wyłącznie: rozpoznawania twarzy, wyszukiwania w Internecie, prowadzenia samochodu) i w niektórych dziedzinach może już dzisiaj przewyższać kompetencje ludzi (np. gra w szachy czy rozwiązywanie równań). Ogólna SI natomiast jest długoterminowym celem wysiłków wielu badaczy, którym zależy na stworzeniu systemów mogących przewyższać człowieka niemal w każdym zadaniu poznawczym ${ }^{22}$.

Znaczny postęp w rozwoju technologii informatycznych przyczynił się również do formowania nowych założeń o charakterze ideologicznym. Mam tu na myśli teorię technologicznej osobliwości (singularity), dataizm i algokrację.

Zwolennicy teorii technologicznej osobliwości - singularitarianie (Singularitarians), jak pisze o nich Joichi Ito ${ }^{23}$, uważaja, że w niedalekiej przyszłości (Ray Kurzweil wskazywał tu rok 2045 ${ }^{24}$ ) doświadczymy największej technologicznej osobliwości w historii ludzkości, czyli takiej, która w ciagu zaledwie kilku lat może obalić instytucje i filary społeczeństwa oraz całkowicie zmienić sposób, w jaki postrzegamy siebie jako istoty ludzkie. Stan technologicznej osobliwości osiagniemy poprzez stworzenie nadludzkiej (super-human) sztucznej inteligencji. Sztuczna inteligencja tego poziomu będzie mogła wyobrazić sobie idee, o których żaden człowiek nie myślał w przeszłości, i wynaleźć narzędzia technologiczne, które będą bardziej wyrafinowane i zaawansowane niż wszystko, czym dysponujemy współcześnie ${ }^{25}$. Jedynym kierunkiem rozwoju ludzkiej cywilizacji, w tak zarysowanym scenariuszu, jest swoista korekta naszej biologicznej natury poprzez asymilację efektów postępu technologicznego, a sztucznej inteligencji w szczególności ${ }^{26}$. Joichi Ito kontrargumentował, iż idea, że istniejemy dla postępu, i postęp ten wymaga nieskrępowanego i gwałtownego wzrostu, jest biczem, który nas biczuje, mając w swym krytycznym stanowisku na myśli przede wszystkim innowatorów i ich naśladowców z Doliny Krzemowej, wierzących w technologiczne możliwości „oswojenia” świata. Wskazywał, że teoria technologicznej osobliwości to naiwna, fałszywa i niebezpieczna religia tych, dla których sztuczna inteligencja jest idealnym partnerem, ponieważ zwiększając szybko swoją zdolność do przetwarzania i wykorzystywania złożoności, pomnaża ich władzę i bogactwo ${ }^{27}$.

Kolejnym ideologicznym nurtem jest dataizm, zakładający wyższość danych nad wszystkimi pozostałymi elementami otaczajacych nas i współtworzonych przez nas rzeczywistości. Wszechświat rozumiany jest tu jako strumień danych, a wkład w ich przetwarzanie wyznacza wartość każdego bytu i zjawiska ${ }^{28}$. Za rozpropagowanie dataizmu Yuval Noah Harari czyni odpowiedzialnymi nauki przyrodnicze, w których to przekroczono granicę pomiędzy tym, co ożywiane i nieożywione, przyjmując, że wszystkie formy życia można rozpatrywać w kategoriach algorytmu. Krok ten, zdaniem Harariego,

\footnotetext{
${ }^{22}$ Future of Life Institute (2020).

${ }^{23}$ Ito (2017).

24 Kurzweil (2006).

25 Tzezana (2017).

26 Zob. Vinge (1993); Kurzweil (2006).

27 Ito (2017).

28 Bloom (2000); Kelly (2010); Hidalgo (2015); DuBravac (2015).
} 
doprowadził do podjęcia coraz skuteczniejszych wysiłków w kierunku stworzenia jednej wszechobejmującej teorii, łączącej wszystkie dyscypliny naukowe, a także do całkowitego przeorganizowania naszego postrzegania i uczestnictwa we wszystkich niemal subświatach codzienności ${ }^{29}$. Dzisiaj, gdy ogrom generowanych danych przekracza analityczne możliwości ludzkiego mózgu, zdaniem dadaistów, konieczne jest powierzenie tych zadań coraz doskonalszym i udoskonalającym się algorytmom, w tym algorytmom SI, czerpiącym informacje ze wszystkich możliwych źródeł, nie tylko naszych mniej lub bardziej świadomych cyfrowych śladów aktywności w sieci, ale też Internetu rzeczy (IoT), kamer monitoringu, mikrofonów i systemów geolokalizacji. Harari przestrzega, że ,jest to obecny naukowy dogmat i że dogmat ten zmienia nasz świat nie do poznania"30, gdyż ludzkość coraz bardziej nie daje sobie rady z zalewem danych, pomimo, a może właśnie na skutek, wprowadzania kolejnych technologicznych innowacji i tworzenia nowych możliwości. A te właśnie w świecie polityki doprowadziły do ukształtowania się następnej ideologii, będącej podstawą nowego systemu zarządzania, jakim jest algokracja.

Algokracja to system zarządzania tworzony przy wykorzystaniu algorytmów, służących do gromadzenia, zestawiania i porządkowania danych, na podstawie których podejmowane są decyzje ${ }^{31}$. Współcześnie, jak słusznie zdaje się zauważać Krzysztof Rybiński, „demokracja zanika i zostaje zastapiona przez algokrację, która jest systemem politycznym, ekonomicznym i społecznym. [...] Jest to wyższa forma ustroju polityczno-społecznego, gdzie ludźmi rządza, w wielu, a potem we wszystkich aspektach życia, algorytmy. Czy tego chcemy czy nie, ten rozwój postępuje” ${ }^{32}$. Dzisiaj jeszcze nie dochodzi do przejmowania władzy przez systemy SI, chociaż perspektywy takie wydają się w bliższej lub dalszej przyszłości całkiem realne ${ }^{33}$. Obecnie to ludzie, odpowiedzialni za zarządzanie i sprawowanie władzy, w tym rządy państw, łączą innowacje technologii informatycznych $\mathrm{z}$ dotychczasowymi regułami systemów prawnych i mechanizmami rynkowymi, tworzac podstawy algokratycznych systemów $^{34}$. Wszyscy bezustannie zostawiamy niezliczone ślady cyfrowe dzięki permanentnemu funkcjonowaniu w dwóch równoległych przestrzeniach codzienności - realnej i wirtualnej. Dzięki temu algorytmy, uczące się na podstawie zbiorów informacji gromadzonych w ogromnych bazach danych, nie tylko zaczynają znać nas lepiej od nas samych ${ }^{35}$, lecz także dysponują niespotykanym dotychczas potencjałem kontroli społecznej. Potencjał ten coraz szerzej wykorzystywany jest do zarządzania i sprawowania władzy zarówno w skali wybranych społecznych przestrzeni - grup zawodowych, organizacji czy przedsiębiorstw, jak i w skali całych społeczeństw, czego najbardziej zaawansowanym przykładem jest chiński System Zaufania Społecznego.

\footnotetext{
29 Harari (2018).

30 Harari (2018):166.

31 Aneesh (2009); Danaher (2016).

32 Rożyński (2020).

33 Bostrom (2016); Kaplan (2019).

34 Aneesh (2009).

35 Harari (2018).
} 
Wszystkie, z konieczności skrótowo naszkicowane tendencje, w ostatnich latach doprowadziły do znacznego wzrostu tempa przemian cywilizacyjnych, w zasadzie nieporównywalnego do czegokolwiek w przeszłości. Dzięki temu na naszych oczach powstaje „nowy świat”, w którym formują się dwie przestrzenie teraźniejszości - subświat teraźniejszej przeszłości i subświat teraźniejszej przyszłości. Obydwa subświaty w niektórych obszarach nakładają się na siebie i łączą, kształtując przestrzenie graniczne, a ich liminalnośćc $c^{36}$ tworzy nowe jakości.

Subświaty teraźniejszej przeszłości i teraźniejszej przyszłości to przestrzenie wpisujące się w zbiór wszystkich, różnorodnych rzeczywistości konstruowanych w otaczającej nas współczesności, od świata życia codziennego w skali mikrostruktur zaczynając, a na subświatach polityki czy biznesu w skali globalnej kończąc. To swoiste perspektywy modyfikujące przebieg podejmowanych działań, kształtowane zarówno z wykorzystaniem uznawanych systemów norm i wartości, stanowiących konsekwencje procesów socjalizacji i kontroli społecznej, jak i na podstawie negocjacji oraz wzajemnych ustaleń aktorów definiujących zróżnicowane sytuacje interakcji wzajemnych ${ }^{37}$. To specyficzne „schematy” postrzegania otaczających nas i współtworzonych przez nas rzeczywistości oraz podobne „schematy” podejmowania w tych rzeczywistościach działań przez realizację różnorodnych ról społecznych. Subświat teraźniejszej przeszłości wcale nie musi charakteryzować się dominacją orientacji tradycjonalistycznej czy skrajnie konserwatywnej, podobnie jak i subświat teraźniejszej przyszłości nie oznacza profuturystycznej orientacji podejmowanych działań. Obydwie przestrzenie symbolizują natomiast usytuowanie poszczególnych jednostek wobec szybko zachodzących zmian cywilizacyjnych, co również wcale nie musi determinować całkowitego braku umiejętności włączania się $\mathrm{w}$ nurt przemian czy korzystania $\mathrm{z}$ ich dobrodziejstw. Mam tu raczej na myśli sposób, albo mówiąc precyzyjniej: sposoby, pełnienia roli przedstawiciela własnego pokolenia ${ }^{38} \mathrm{w}$ szerszych kontekstach zmieniającej się współczesności.

W szczególności interesuja mnie modyfikacje cech charakteryzujących tożsamość społeczną pokoleń, a prowadzące do zmian w procesach ich dyferencjacji. Uściślając, prezentowane w niniejszym tekście diagnozy przemian w świecie pokoleń dotyczą trzech polskich pokoleniowych zbiorowości: pokolenia powojennego wyżu demograficznego z jego trzema grupami pokoleniowymi - pokoleniem '68 (roczniki 1942-1949), pokoleniem lat 70. (1950-1955)

${ }^{36}$ Por. Martin (1985); Turner (2008).

${ }^{37}$ Schutz (1974); Berger, Luckmann (1991); Garfinkel (1967); Cicourel (1973); Mead (1934/1967); Zimmermann, Pollner (1971).

${ }^{38}$ Rola przedstawiciela własnego pokolenia to de facto zespół ról tworzacy się na podstawie dokonywanych przez jednostki wyborów spośród istniejących scenariuszy podejmowania poszczególnych ról społecznych w danym miejscu i czasie. Jest to rola, w pełnieniu której odnajdziemy zbiór cech identyfikacyjnych pokoleń, a jej modyfikacje podejmowania i pełnienia decyduja o wyrazistości grup pokoleniowych oraz są współodpowiedzialne za specyfikę tworzenia ich społecznej tożsamości. Modyfikacje te stanowią podstawę stylu charakteryzującego w danym miejscu i czasie życie codzienne najpierw młodzieży, a później coraz starszych grup pokoleniowych, chociaż często pozostają nie w pełni uświadamiane przez działające jednostki, zob. Wrzesień (2003). 
i pokoleniem '80 (1956-1963) ${ }^{39}$, pokolenia końca wieku (1964-1982) i milenialsów (1983-1998). Pierwsze trzy grupy pokoleniowe to polscy rówieśnicy pokolenia baby boomers w Stanach Zjednoczonych i w Europie Zachodniej (a najstarsi - również młodszych przedstawicieli silent generation). Pokolenie końca wieku to polski odpowiednik generation $X^{40}$. Milenialsi natomiast w Polsce noszą tę samą pokoleniową nazwę co młodzi ludzie w krajach zachodnich. Wszystkie wskazane ramy są oczywiście umowne, gdyż o zakwalifikowaniu do poszczególnych grup pokoleniowych, zgodnie z przyjmowaną socjologiczna perspektywą analiz pokoleń, decyduja manifestacje cech pokolenia w życiu codziennym, a nie sam fakt urodzenia w określonym roku ${ }^{41}$.

Kształtujące się współcześnie nowe subświaty „nowego świata” coraz liczniej zasiedlaja „nowi ludzie”, a właściwie modyfikacji ulegają ich sposoby definiowania sytuacji i podejmowania działań w dynamicznie zmieniających się rzeczywistościach, w których toczy się ich życie. Zasygnalizowana powyżej tendencja nie dotyczy jedynie najmłodszych spośród milenialsów, gdyż proces intensywnych przemian cywilizacyjnych de facto jest elementem procesu socjalizacji, któremu podlegają od początku swojego życia, co sytuuje ich w obszarach teraźniejszej przyszłości i dla tych kategorii wiekowych wydaje się stanem naturalnym. Poza tym proces kształtowania tożsamości społecznej ich pokolenia jeszcze się nie zakończył.

Dziś zarówno w relacjach między-, jak i wewnątrzpokoleniowych swoją obecność coraz wyraźniej zaznaczają dwa typy realizacji roli przedstawiciela własnego pokolenia. Umownie będę używał tu określeń „ludzie przeszłości” i „ludzie przyszłości”. Jedni i drudzy, mimo życia razem, w tych samych przestrzeniach współczesności, żyją jakby obok siebie, w dwóch równoległych, chociaż przenikających się sferach: teraźniejszej przeszłości i teraźniejszej przyszłości. Czerpią korzyści z efektów tego samego przebiegu przemian cywilizacyjnych, ale postrzegaja je z innych perspektyw i uczestniczą w nich nieco inaczej, choć pozornie tych różnic nie ma. Oczywiście skrajne bieguny wypełnia liczne grono rozmaitych „odcieni szarości” i dwa wskazane powyżej typy należy traktować $\mathrm{w}$ kategoriach typów idealnych ${ }^{42}$.

„Ludzi przyszłości” odnajdziemy we wszystkich interesujących nas pokoleniach, jednakże, z obiektywnych przyczyn, w starszych grupach pokoleniowych jest ich mniej. Natomiast wśród najmłodszych spośród milenialsów „ludzie przyszłości” stanowią większość. Nie wszystkie omówione poniżej cechy musza w pełnych zakresach charakteryzować „ludzi przeszłości” i „ludzi przyszłości”. Stanowią one jedynie zbiór cech wyróżniających, pomocnych przy kwalifikacji jednostek do poszczególnych typów realizacji roli przedstawiciela własnego pokolenia. Tymczasem, biorąc pod uwagę interesujące nas procesy cywilizacyjne, podział na „ludzi przyszłości” i „ludzi przeszłości” wydaje się bardziej istotny niż ich przynależność do poszczególnych grup pokoleniowych.

39 Zob. Fatyga (1999).

40 Spopularyzowany w mediach po cyklu artykułów w Gazecie Wyborczej pt. „Młodzi końca wieku".

41 Zob. Wrzesień (2003), (2009).

${ }^{42}$ Weber (2004). 
„Ludzie przyszłości” wpisują się ze swoją aktywnością w dataistyczne perspektywy współtworzenia otaczających nas rzeczywistości poprzez mniej lub bardziej intensywną realizację dataistycznego hasła: „Jeśli czegoś doświadczasz - rejestruj. Jeśli coś rejestrujesz - przesyłaj. Jeśli coś przesyłasz udostępniaj”"33. „Ludzie przyszłości” nie rozstają się ze smartfonami (czasem i tabletami), a stała łączność ze światem wirtualnym traktują jako jedna z podstaw egzystencji. Z entuzjazmem korzystają z pojawiających się nowinek technologii informatycznych, a bogactwo ich możliwości wykorzystują do tworzenia nowych form wspólnej partycypacji.

Szczególną wartością dla „ludzi przyszłości” jest właśnie partycypacja w równoległej - nierównoległej przestrzeni internetowo-telefonicznej. Świat dla „ludzi przyszłości” przestaje dzielić się na realny i wirtualny, a zastępuje go jedna realno-wirtualna rzeczywistość, w której płynność granic stwarza pozory ich braku. Dla „ludzi przyszłości” granice pomiędzy przestrzenią wirtualną a realną na tyle uległy rozmyciu, że to, czego mogą doświadczyć poprzez aktywność w sieci, jest tak samo ważne, jak doświadczenia w świecie rzeczywistym. W ten sposób „ludzie przyszłości” tworzą terytoria graniczne, a ich liminalność znacząco zmienia konstruowane dotychczas pokoleniowe subświaty. W rzeczywistości jednak nowe technologie, w tym wykorzystywane przez smartfony, izoluja „ludzi przyszłości” od świata realnego i powoduja że coraz bardziej tracą oni zdolność doświadczania go bez elektronicznego gadżetu.

Ponadto, z powodu swoistego, stałego zanurzenia w internetowych przestrzeniach, „ludzie przyszłości” posiadają słabsze umiejętności komunikacji bezpośredniej. Preferuja krótkie, proste przekazy, dlatego wolą komunikować się za pośrednictwem maili, SMS-ów, portali społecznościowych, komunikatorów, czatów, forów itp. Słowa zastępują emotikonami i lajkami, za pomoca których wyrażaja swoje emocje, aprobatę lub jej brak. Chęć zdobycia jak największej liczby lajków i komentarzy jest dla nich bardzo silną motywacją do działania ${ }^{44}$.

„Ludzi przyszłości” cechuje też specyficzne postrzeganie „ludzi przeszłości”. Traktują ich trochę tak, jakby byli niechcianymi gośćmi-intruzami w „ich świecie", świecie, który dopiero się zaczął, zaczął się z nastaniem ich pokolenia. Im młodsi „ludzie przyszłości”, tym skłonność ta ulega nasileniu. Dla „ludzi przyszłości” „ludzie przeszłości” są niczym „desant” niepasujących do teraźniejszej przyszłości norm, wartości i wzorów zachowań. Wiele przykładów naszkicowanej powyżej orientacji bez trudu odnajdziemy w internetowych przestrzeniach, chociaż najczęściej łączy się ona ze specyfiką relacji międzypokoleniowych. „Pamiętasz czasy bez komórek, smartfonów i Internetu? Jeśli tak, to jesteś przybyszem z przeszłości. Przyszłość należy do pokolenia Z, które urodziło się już z kontem na Facebooku i Wi-Fi w pępowinie" ${ }^{45}$. Postrzeganie przeszłości przez coraz młodszych „ludzi przyszłości” dobrze ilustrują słowa:

43 Harari (2018): 173.

44 Szerzej analizą sygnalizowanych tu zjawisk, w tym przestrzeni nowych uzależnień behawioralnych, zająłem się gdzie indziej zob. Wrzesień (2014), (2015), (2016).

${ }^{45}$ Rojewska (2020). 
„Cywilizacja już nie istnieje. Nie ma Internetu. Ani telewizji. Ani telefonów komórkowych. Nie ma niczego, co przypominałoby ci, że jesteś ludzką istotą"46. Chociaż jest to fragment recenzji książki Manuela Loureiro, stwierdzenie, że o naszym człowieczeństwie świadczy dostęp do telefonu komórkowego czy Internetu, wyraźnie odzwierciedla sposób oglądu rzeczywistości osób urodzonych po $1990 \mathrm{r}$.

„Ludzie przyszłości” są mało podatni na dotychczas skuteczne mechanizmy systemów kontroli społecznej. Nasilenie tej cechy wydaje się wprost proporcjonalne do wieku. Im młodsi, tym podatność mniejsza. Za fakt ten odpowiedzialne sa zapoczątkowane w połowie lat osiemdziesiątych XX w. modyfikacje procesów socjalizacji ${ }^{47}$, które spowodowały szereg zmian prowadzących do zaburzeń w istniejących systemach społecznej kontroli ${ }^{48}$. Rodzice, stopniowo dystansując się od dawnych metod, wprowadzili nowa jakość w ramach wewnątrzrodzinnych systemów socjalizacyjno-kontrolnych, a centralną cechą stała się płynność i nieostrość granic obowiązujących reguł. W konsekwencji wypowiedzenie lojalności obowiązującym normom (anomia), staje się coraz bardziej powszechne. „Ludzie przyszłości” częściej niż „ludzie przeszłości” skłonni są do nieprzestrzegania lub modyfikowania obowiąujących norm.

Z tej to, w znacznym stopniu, przyczyny powstał w Chinach System Zaufania Społecznego. W kraju tym co prawda mieliśmy do czynienia z definicyjnym wręcz rozwojem stanu anomii w czasach prosperity ${ }^{49}$, który doprowadził do załamania się dotychczasowych systemów normatywnych ${ }^{50}$. Niemniej jednak skuteczność wprowadzonych tam zalgorytmizowanych sposobów przywoływania do porządku i wypracowywania zachowań pożądanych może okazać się w niedalekiej przyszłości nową formą społecznej kontroli adresowaną do „ludzi przyszłości” także poza Państwem Środka. Już dzisiaj w ten sposób możemy postrzegać wprowadzane na całym świecie zalgorytmizowane systemy wywierania wpływu (ADM), a także rosnącą powoli popularność osobistych asystentów (intelligent virtual assistant - IVA lub intelligent personal assistant-IPA), takich jak na przykład Siri, Cortana czy Alexa. Z roku na rok coraz bardziej udoskonalani osobiści asystenci, wykorzystujący technologię SI, niebawem zapewne zagoszczą w nowych systemach kontroli społecznej, pomagając w podejmowaniu działań zgodnych z obowiązującymi regulacjami normatywnymi lub w zaniechaniu zachowań od nich odbiegających. Sądzę, że „ludzie przyszłości”, żyjący równolegle w dwóch przestrzeniach: realnej i wirtualnej, poddający się permanentnej ocenie i kontroli w sieci (gdyż nieustannie coś upubliczniaja) wydają się podatni na mechanizmy zarządzania za pośrednictwem algorytmów, a co za tym idzie - algokracja nie będzie wzbudzać w nich negatywnych emocji. Do „ludzi przyszłości”, poszukujących prostych i szybkich odpowiedzi na nurtujące ich pytania oraz nieskomplikowanych rozwiązań problemów,

\footnotetext{
46 Onet.pl (2019).

${ }^{47}$ Wrzesień (2009), (2014).

48 Wrzesień (2017), (2019).

49 Durkheim (2005).

${ }^{50}$ Persson, Vlaskamp, Obbema (2015).
} 
mogą lepiej przemawiać jasne przekazy oparte na algorytmach. Przekazy nie pozostawiajace pola do interpretacji, dyskusji czy polemiki.

Dla „ludzi przeszłości”, zachodzacy na ich oczach i z ich udziałem, proces szybkich cywilizacyjnych zmian jest jak spektakl z atrakcyjnymi scenami, w których od czasu do czasu sami decydują się wziąć udział. Nie rejestrują ani nie udostępniają wszystkiego, w czym uczestnicza, i nie sprawdzaja co chwilę, ile zgromadzili lajków. Nie oznacza to, że w ogóle nie zostawiają świadomie cyfrowych śladów w sieci. Mają konta na portalach społecznościowych, korzystają ze smartfonów. Dla nich jednak korzystanie z technologicznych nowinek funkcjonalnie służy podwyższaniu jakości życia, to furtka do nowych możliwości, traktowana bez emocji, jak na przykład lodówka, również bardzo przydatna na co dzień. Dlatego też w tym przypadku nie dochodzi do rozmycia granic pomiędzy przestrzenią realną i wirtualną.

„Ludzie przeszłości” lepiej niż „ludzie przyszłości” odnajdują się w przestrzeniach komunikacji bezpośredniej. Posługują się pocztą elektroniczną i piszą SMS-y, udzielają się też na portalach społecznościowych, korzystają z komunikatorów, nie stronią również od załatwiania spraw, na przykład w banku poprzez chatboty, niemniej relacje bezpośrednie face to face oraz rozmowy przez telefon wciąż są dla nich najbardziej satysfakcjonujaccym typem relacji, który jeżeli mogą wybierać, preferujac.

W obszarach oddziaływań socjalizacyjnych i kontrolnych „ludzie przeszłości” w zasadzie podlegaja od lat wypracowywanym i sprawdzonym regułom. Nie oznacza to oczywiście, że nie przekraczają obowiązujacych norm, a ze względu na postępująca globalną anomię ${ }^{51}$ skłonności do nieprzestrzegania norm przez „ludzi przeszłości” też ulegają nasileniu. Niemniej jednak procesy przywoływania niesubordynowanych „ludzi przeszłości” do porządku i wypracowywania u nich zachowań pożądanych - naczelne cele systemów kontroli społecznej ${ }^{52}$ - nie wymagaja znaczących modyfikacji stosowanych dotychczas mechanizmów kontroli.

W odróżnieniu od „ludzi przyszłości”, „ludzie przeszłości” moga podchodzić bardziej krytycznie do pojawiających się nowych form kontroli społecznej, w tym i tych, które niosą za sobą algokracja i dataizm. Ponieważ wolą kontakt bezpośredni w komunikacji oraz zrozumiałe reguły postępowania, rozwiązania oparte na algorytmach moga wydawać się im niezrozumiałe i sztuczne, a zatem wzbudzać niechęć, lęk, a nawet wrogość. Oni pragną wyjaśnień, chcieliby móc się wytłumaczyć, porozmawiać o problemie, jednakże algorytmizacja na to nie pozwala. Dlatego też algokracja nie wydaje się pożądanym systemem, w którym będą dobrze czuli się „ludzie przeszłości”. Szaleńcze tempo postępu technologicznego spowodowało, że mieli oni zbyt mało czasu na dostosowanie się do zmian, rewizję przyzwyczajeń, sposobu myślenia i postrzegania rzeczywistości oraz swojego w niej miejsca. O ile smartfon, oprócz swoich licznych dodatkowych funkcji, jest nadal telefonem i można z niego korzystać lub też nie, o tyle algorytmiczna rzeczywistość (a w niedalekiej przyszłości także sztuczna

\footnotetext{
51 Por. Passas (2000).

52 Por. Sztompka (1967).
} 
inteligencja) zaczyna otaczać wszystkich, nie pozostawiając im prawa wyboru. Ponadto może być odbierana przez „ludzi przeszłości” jako twór obcy, stworzony przez globalne korporacje ponadnarodowe, a nie lokalne instytucje rządowe czy komercyjne. Niestety, ci, którzy nie chca płynąc z nurtem globalnej rewolucji technologicznej, nie będą mogli już żyć po swojemu, spokojnie na jej peryferiach, lecz będą zmuszeni do przystosowania się, w przeciwnym razie pozbawieni zostaną możliwości funkcjonowania we współczesnym świecie. „Ludzie przeszłości” mogą wykazywać zatem silniejszą skłonność do podawania w wątpliwość algorytmicznych decyzji (systemów ADM), wskazując ich nierzetelność czy niesprawiedliwość.

„Ludzie przeszłości” częściej też niż „ludzie przyszłości” sytuują się na pozycjach zwolenników dotychczasowego ładu społecznego, co na przykład w ostatnich latach mogliśmy obserwować w przestrzeniach obrońców konstytucji w Polsce. „Ludzie przyszłości” z kolei chętniej angażują się w akcje dotyczące dalszych losów naszej planety oraz spektakularne happeningi, którymi mogą pochwalić się w sieci. Wspólną płaszczyzną dla „ludzi przeszłości” i „,ludzi przyszłości" jest np. Facebook czy Twitter. Odnajdziemy tu jednych i drugich. Podobnie w licznych poststart-upowych obszarach nowych form biznesowej aktywności firm, takich jak Airbnb, Uber, Netflix czy Spotify. To przestrzenie graniczne subświatów teraźniejszej przeszłości i teraźniejszej przyszłości. Sa one interesującą i ważną sceną zarysowującego się podziału. „Ludzie przeszłości”, na przykład, widzą w Airbnb kontynuację wcześniejszych tendencji rynku turystycznego, symbolizowanych niegdyś przez Interhome czy Novasol, a później Booking.com. Natomiast dla „ludzi przyszłości” wskazywana tu rzeczywistość zaczyna się (dosłownie i w przenośni) od Airbnb. Dotyczy to również pozostałych, przywołanych powyżej przykładów.

Ktoś w tym miejscu może powiedzieć, że przecież „ludzie przeszłości” i „ludzie przyszłości" byli zawsze. Jedni szybciej przystosowują się do zmian, drudzy wolniej, inni wcale. Współcześnie jednak występują dwa niespotykane nigdy wcześniej elementy, które mają decydujący wpływ na charakter tego podziału. Po pierwsze, aktualnie istnieją dwie równoległe rzeczywistości: realna i wirtualna. Świat cechuje swoista schizofreniczna dwoistość, a dla części ludzi w nim żyjących oba subświaty sa jednakowo ważne. Po drugie, w czasach minionych żadna z innowacji nie wpływała na życie wszystkich ludzi. Można było z nich zrezygnować i żyć jak dotychczas (nie jeździć koleja, samochodem, nie oglądać telewizji, nie posiadać telefonu itd.). Obecnie technologie informatyczne są wszechobecne i wszechogarniające, a zwiazana z nimi algorytmizacja i sztuczna inteligencja mają wpływ na życie każdej jednostki, nawet wbrew jej woli. Ponadto dawniej „ludzie przyszłości”, będąc innowatorami zmian cywilizacyjnych kontynuowali wcześniejsze tendencje całkowicie się od nich nie odcinając. Silnik parowy, elektryczność czy radio mimo silnego wpływu na życie ludzi, stanowiły następstwo wcześniej występujacych form napędu, energii czy komunikacji. Dzisiejsi „ludzie przyszłości”, będąc innowatorami zmian, tylko w niewielkim stopniu kontynuuja to, co było wcześniej, a zdecydowanie częściej zrywają z tradycją rozwoju cywilizacyjnego. 
Omówione powyżej tendencje kształtuja nowy wymiar procesu dyferencjacji pokoleń, który będąc elementem procesu zmiany pokoleń, określa wewnętrzne zróżnicowania głównie w obrębie szerszych pokoleniowych zbiorowości. Mam tu na myśli dwa typy dyferencjacji pokoleń: pionowe i poziome. Dyferencjacje pionowe przejawiaja się przede wszystkim w nasilaniu się tendencji izolacjonistycznych pomiędzy sasiadującymi bliskimi generacjami, zarówno w ramach szerszej pokoleniowej zbiorowości, jak i na pograniczu dwóch szerokich pokoleniowych kręgów. Dyferencjacje poziome natomiast charakteryzują się występowaniem znacznej liczby kulturowych różnorodności w obrębie pokoleń (preferencji, mód, fascynacji, subkultur), chociaż ich mnogość i wielopostaciowość wcale nie musi oznaczać wzajemnej rywalizacji ${ }^{53}$. Zarysowujący się współcześnie podział na subświaty teraźniejszej przeszłości i teraźniejszej przyszłości wraz z zasiedlającymi je „ludźmi przeszłości” i „ludźmi przyszłości” to nowa forma dyferencjacji pokoleń. Zróżnicowania te przekraczają granice pokoleń istniejących, dodając „trzeci wymiar”, kształtujący się obok diagnozowanych dotychczas dyferencjacji pionowych i poziomych.

„Ludzie przyszłości” mogą znacznie różnić się wiekiem, a za sprawą podobieństw preferencji normatywnych, uznawanych wartości czy realizowanych wzorów zachowań bez trudu odnajdywać wspólne płaszczyzny porozumienia. Na przykład „ludzie przyszłości” z pokolenia końca wieku mogą bez przeszkód znaleźć wspólny język z „ludźmi przyszłości” spośród milenialsów. Podobny mechanizm dotyczy również „ludzi przeszłości”. „Ludzie przyszłości” i „ludzie przeszłości” w okresie kształtowania tożsamości społecznej pokolenia w realizowanym stylu życia przenoszą liczne cechy identyfikacyjne własnych pokoleń i są ich rozpoznawalnymi przedstawicielami. Różni ich natomiast usytuowanie w obszarach teraźniejszej przeszłości i teraźniejszej przyszłości, a także inny sposób realizacji roli przedstawiciela własnego pokolenia.

Dynamika dzisiejszych przemian cywilizacyjnych sprzyja intensyfikacji podziałów wewnątrzpokoleniowych. „Ludzi przyszłości” łączy więcej z podobnymi sobie przedstawicielami innych pokoleń, niż z „ludźmi przeszłości”, wywodzącymi się z ich własnych grup pokoleniowych. A zatem nastawienie do toczących się zmian, aktywne włączanie się w ich nurt odgrywa tu rolę zasadnicza. W efekcie dochodzi do zerwania istniejacych więzi wewnątrzpokoleniowych, co być może będzie skutkowało koniecznością zdefiniowania tych pokoleń na nowo.

\section{PODSUMOWANIE}

Zaprezentowane w niniejszym artykule rozważania traktuję w kategoriach hipotez, wymagajacych pogłębionych badań w celu dalszej ich weryfikacji, które zamierzam przeprowadzić w najbliższej przyszłości. Poczynione

${ }^{53}$ Zob. Wrzesień (2003). 
dotychczas obserwacje pozwalają na sformułowanie kilku ogólnych wniosków dotyczących potencjalnego rozwoju opisywanych w artykule procesów.

Współcześnie wydaje się, że zwolennicy teorii osobliwości mają rację, uważając, że doświadczany przez nas postęp cywilizacyjny nie ulegnie spowolnieniu, przynajmniej w zakresie rozwoju nowych technologii informatycznych. Bazujace na nim dataistyczne sposoby tworzenia różnorodnych rzeczywistości świata życia codziennego, partycypacji w nich, a także ich ewaluacji i kontroli będa coraz bardziej rozpowszechniać się, i to zarówno w skali mikro-, jak i makrospołecznej. Dzięki temu podział świata pokoleń na subświat teraźniejszej przeszłości i teraźniejszej przyszłości (wraz z „zamieszkującymi” je „ludźmi przeszłości” i „ludźmi przyszłości”) będzie się pogłębiał.

Stale rosnace tempo cywilizacyjnych zmian sprzyja i nadal sprzyjać będzie nasilaniu się tendencji izolacjonistycznych zarówno w relacjach występujących dotychczas w świecie pokoleń między bliskimi generacjami i szerszymi pokoleniowymi zbiorowościami (dychotomia młodzi-starzy), jak i w trzecim wymiarze dyferencjacji pokoleniowych - w relacjach pomiędzy „ludźmi przeszłości” i „ludźmi przyszłości”.

Prowadzone dziś na szeroką skalę prace nad udoskonalaniem technologii informatycznych zarówno przez instytucje państwowe, jak i podmioty komercyjne z czasem będą coraz silniej modyfikować procesy socjalizacji i społecznej kontroli, przybliżając nas do algokracji. „Ludzie przyszłości” to ludzie nowego ładu społecznego. Już dzisiaj aktywnie go współtworza, zarówno w profesjonalnych sferach branży IT, jak i w „zwykłych” przestrzeniach codzienności. Algorytmiczna współczesność to ich naturalne środowisko, dlatego reguły, które w niej zaczynają obowiązywać, jest im łatwiej zaakceptować. „Ludzie przeszłości” natomiast, dla których podważanie i kwestionowanie dawnych norm społecznych przez „ludzi przyszłości” bywa często niezrozumiałe, w przestrzeniach nowych zasad czują się trochę jak na obcym terenie. Między „ludźmi przeszłości” i „ludźmi przyszłości” toczy się obecnie swoista „wojna”, a jest to „wojna” między starym i nowym ładem społecznym. Trudno w tym miejscu prognozować dalszy jej przebieg, jednakże wydaje się, że - tak jak bywało już nieraz w przeszłości - najlepszym rozwiązaniem toczącego się sporu byłoby powstanie hybrydy łączącej najkorzystniejsze, z punktu widzenia zarówno jednostek, jak i całych społeczeństw, elementy starego i nowego porządku. Ekspansywność nowego ładu nakazuje jednak z wielką ostrożnością spodziewać się takiego rozwiązania.

Aneesh, A. (2009). Global labor: algocratic modes of organization. Sociological Theory 27(4): 347370 .

Beer, D. (2017). The social power of algorithms. Information, Communication \& Society 20(1): $1-13$.

Berger, P.L., Luckmann, T. (1991). The Social Construction of Reality: A Treatise in the Sociology of Knowledge. London.

Bloom, H. (2000). Global Brain. The Evolution of Mass Mind from the Big Bang to the 21st Century. New York.

Bostrom, N. (2016). Superinteligencja. Scenariusze, strategie, zagrożenia. Tłum. D. Konowrocka-Sawa. Gliwice. 
Cicourel, A. (1973). Cognitive Sociology. Harmondsworth.

China Law Translate (2020). Legal Documents Related to the Social Credit System. <https:// www.chinalawtranslate.com/en/social-credit-documents/>.

Danaher, J. (2016). The threat of algocracy: reality, resistance and accommodation. Philosophy and Technology 29(3): 245-268.

DuBravac, S. (2015). Digital Destiny: How the New Age of Data Will Transform the Way We Work, Live and Communicate. Washington.

Durkheim, É. (2005). Suicide: A Study in Sociology. London-New York.

Encyklopedia PWN online. <https://encyklopedia.pwn.pl/>.

Fatyga, B. (1999). Dzicy z naszej ulicy. Antropologia kultury młodzieżowej. Warszawa.

Future of Life Institute (2020). <https://futureoflife.org/>.

Gardner, H., Davis, K. (2013). The App Generation: How Today's Youth Navigate Identity, Intimacy, and Imagination in a Digital World. New Haven-London.

Garewicz, J. (1983). Pokolenie jako kategoria socjofilozoficzna. Studia Socjologiczne 88(1): 75-87.

Garfinkel, H. (1967). Studies in Ethnomethodology. Englewood Cliffs.

Harari, Y.N. (2018). Homo deus. Krótka historia jutra. Tłum. M. Romanek. Kraków.

Hidalgo, C. (2015). Why Information Grows: The Evolution of Order, from Atoms to Economies. New York.

Ito, J. (2017). Resisting reduction: a manifesto. Designing our complex future with machines. Journal of Design and Science. doi:10.21428/8f7503e4

Ito, J. (2019). Forget about artificial intelligence, extended intelligence is the future. Wired 24 kwietnia.

Iwasiński, Ł. (2016). Społeczne zagrożenia danetyzacji rzeczywistości, [w:] B. Sosińska-Kalata (red.), Nauka o informacji w okresie zmian. Informatologia i humanistyka cyfrowa. Warszawa: $135-146$.

Kaplan, J. (2019). Sztuczna inteligencja. Co każdy powinien wiedzieć. Tłum. S. Szymański. Warszawa.

Kelly, K. (2010). What Technology Wants. New York.

Kopka, A. (2018). Azjatycki Wielki Brat, czyli Social Credit System. CSPA. <http://www.polskaazja.pl/a-kopka-azjatycki-wielki-brat-czyli-social-credit-system/>.

Kreft, J. (2018). Władza algorytmów mediów - między reifikacją a rynkiem. Zarządzanie w kulturze 19(1): 11-28.

Krzysztofek, K. (2012). Big data society. Technologie samozapisu i samopokazu: ku humanistyce cyfrowej. Kultura i Historia 21. <https://www.kulturaihistoria.umcs.lublin.pl/pl/archives/3626>.

Kurzweil, R. (2006). The Singularity Is Near: When Humans Transcend Biology. New York.

Mannheim, K. (1928/1952). The problem of generations, [w:] Essays on the Sociology of Knowledge. London: $276-320$.

Martin, B. (1985). A Sociology of Contemporary Cultural Change. Oxford.

Mead, G.H. (1934/1967). Mind, Self, and Society. Chicago.

Mikułowski-Pomorski, J. (1968). Pokolenie jako pojęcie socjologiczne. Studia Socjologiczne 3/4(30/31): 267-281.

Onet.pl. (2019). 10 hiszpańskich powieści ostatnich lat, które trzeba znać. <https://kultura.onet. $\mathrm{pl} / \mathrm{ksiazki} / 10$-hiszpanskich-powiesci-ostatnich-lat-ktore-trzeba-znac/k0lkqh1>.

Ortega y Gasset, J. (1961). The Modern Theme. New York - Evanston - London.

O’Neil, C. (2017). Broń matematycznej zagłady. Jak algorytmy zwiększają nierówności i zagrażają demokracji. Tłum. M. Zieliński. Warszawa.

Ossowska, M. (1963). Koncepcja pokolenia. Studia Socjologiczne 9(2): 47-51.

Passas, N. (2000). Global anomie, dysnomie, and economic crime: hidden consequences of neoliberalism and globalization in Russia and around the world. Social Justice 27(2): 16-44.

Persson, M., Vlaskamp, M., Obbema, F. (2015). China rates its own citizens - including online behaviour. de Volkskrant, 25 kwietnia 2015.

$<$ https://www.volkskrant.nl/nieuws-achtergrond/china-rates-its-own-citizens-including-online be haviour b4c0ae0e/?referer=https\%3A\%2F\%2Fwww.google.com $\% 2 \mathrm{~F}>$

Rojewska, M. (2020). Milenialsi, pokolenie Z, Y, X, generacja baby boomers - kto to? <https:// interviewme.pl/blog/pokolenie-z>. 
Rożyński, P. (2020). Krzysztof Rybiński: Demokracja zanika i zastępuje ją algokracja. Rzeczpospolita, 19 stycznia 2020.

Schütz, A. (1974). Der sinnhafte Aufbau der sozialen Welt. Frankfurt am Mein.

Simmel, G. (1908). Soziologie. Untersuchungen über die Formen der Vergesellschaftung. Leipzig.

Shannon, C.E. (1940). A symbolic analysis of relay and switching circuits. Master thesis. Department of Electrical Engineering, Massachusetts Institute of Technology.

Sztompka, P. (1967). Teoria kontroli społecznej. Kultura i Społeczeństwo 11(3): 131-149.

Świda-Ziemba, H. (1999). Wartości egzystencjalne młodzieży lat dziewięćdziesiątych. Warszawa.

Turner, V. (2008). The Ritual Process: Structure and Anti-Structure. New Brunswick-London.

Twenge, J.M. (2017). iGen: Why Today's Super-Connected Kids Are Growing Up Less Rebellious, More Tolerant, Less Happy And Completely Unprepared for Adulthood (And What This Means for the Rest of Us). New York.

Tzezana, R. (2017). Singularity: explain it to me like i'm 5-years-old. Here's how to understand the merger of humans and robots. Futurism.com.

Valentine, S. (2019). Impoverished algorithms: misguided governments, flawed technologies, and social control. Fordham Urban Law Journal 46(2): 364-427.

Vinge, V. 1993. The coming technological singularity: how to survive in the post-human era, [w:] NASA. Lewis Research Center. Vision 21: Interdisciplinary Science and Engineering in the Era of Cyberspace: $11-22$.

Weber, M. (2004). The 'objectivity' of knowledge in social science and social policy, [w:] S. Whimster (ed.), The Essential Weber. London-New York.

Wrzesień, W. (2003). Jednostka - rodzina - pokolenie. Studium relacji międzypokoleniowych w rodzinie. Poznań.

Wrzesień, W. (2009). Europejscy Poszukiwacze. Impresje na temat współczesnego pokolenia polskiej młodzieży. Warszawa.

Wrzesień, W. (2014). Modyfikacje wzorów socjalizacyjnych w rodzinie w czasach nałogowych konsumentów. Ruch Prawniczy, Ekonomiczny i Socjologiczny 76(3): 261-280.

Wrzesień, W. (2015). Pokoleniowość współczesnej polskiej młodzieży. Władza Sądzenia 7: 37-55.

Wrzesień, W. (2016). Kilka uwag o pokoleniowej sytuacji współczesnej polskiej młodzieży. Ruch Prawniczy, Ekonomiczny i Socjologiczny 78(1): 229-241.

Wrzesień, W. (2017). Współczesne oblicza anomii. Ruch Prawniczy, Ekonomiczny i Socjologiczny 79(4): $285-304$.

Wrzesień, W. (2017a). Zmiana pokoleń w czasach globalnej anomii. Societas/Communitas 24(2): $37-52$.

Wrzesień, W. (2019). O (de)kompozycjach współczesności. Ruch Prawniczy, Ekonomiczny i Socjologiczny 81(3): 251-265.

Zimmermann, D.H., Pollner, M. (1971). The everyday world as a phenomenon, [w:] J.D. Douglas (ed.), Understanding Everyday Life: Towards a Reconstruction of Sociological Knowledge. London: 80-103.

\section{GENERATIONAL TRAITS IN THE WORLD OF SMARTPHONES, ALGORITHMIZATION AND ARTIFICIAL INTELLIGENCE}

\section{Sum mary}

In recent years, significant changes in almost all areas of everyday life have occurred due to the constant acceleration of civilizational progress, mainly caused by the dynamic development of information technologies. As a result of these changes, new territories of generational relations (sub-worlds of the present-past and the present-future) and new dividing lines are being created. Contemporary people play the role of being members of their own generation differently. In the sub-world of generations, we observe more and more clearly visible modifications of the features characterizing generations' social identity and changes in the process of generational differentiation. The presented text is an attempt at a preliminary diagnosis of the changes mentioned above.

Keywords: generation; generational traits; algorithmization 
